\title{
Assessing BIM Integration with Sustainable Requirement for Buildings Construction
}

\author{
Ahmed Mahjoob ${ }^{1}$, Mohammed Mahdi Abed ${ }^{2}$ \\ ${ }^{1,2}$ University of Baghdad, Facility of Engineering, Al-Jadriya, Baghdad, Iraq
}

\begin{abstract}
Because of Increasing Environmental challenges in the world it's become necessary Reliance sustainability as a solution for the problems. Construction industry is considered an influential part in the environmental impact. The sustainable concepts are large processes that the facet need more time and cost with an effort to achieve its goals, that's led to uses the technology to simplifying and speed up the processes and evaluate its economic impact. Building Information Modeling (BIM) is the best technology used for virtual works. Because the claims for BIM and sustainability in the construction industry are increasing annually, it's make attention to research more demand. In this paper we will attempt to investigate by closed questionnaire, the status of using BIM in the Middle East, the challenges that faced by BIM users, most benefits from using BIM technique and, the advantages of BIM to support the concepts of sustainability. The questionnaire form created by using Web-Based survey solutions, after that the questionnaire forms were collected and analyzed statistically, then discussed and the results obtained from the survey. The results shows that most of respondents currently use BIM technology in their projects and about three quarters of respondents adopt sustainable concepts.
\end{abstract}

Keywords: Building information modeling, Sustainability, life cycle cost

\section{Introduction}

Building information modeling (BIM) developed within the past few years in the sector of construction industry with increase the requirement for this industry (4).

Most use of BIM around design problems, lake of coordination in design resolves in design problems, synchronization, building performance and quality.BIM should provide level of solution in terms of optimize of design, but we can think about the ability of BIM in business management including project management, cost management, facilities management, and etc. so the BIM modeling in terms of 4D, 5D, 6D and 7D that's main cost, time, facility management, and sustainability will improve the performance of the project. (2).

This study investigated the status of using BIM in the Middle East. The research objectives is to (1) analyzing the currently trends of BIM with most benefits from using BIM technique, (2) the Challenges that faced by BIM users, (3) determine performing BIM-sustainable analysis project stages, (4) determine what the most types of BIM-sustainability functional analysis are used (5) determine the status of use the Life Cycle costing LCC and the stages of use it as a tool used in sustainable analysis and business management, (6) factors influencing the use of BIM.

To explore the statues of BIM we design a closed questionnaire which agrees with the specific characteristics of the region. The questionnaire forms were collected and analyzed statistically, then discussed and the results obtained from the survey.

\section{Literature Review}

\subsection{Building Information Modeling}

BIM is an intelligent model base process that provides insight to help the person plan, design, construct and manage buildings. (1).

BIM provide coordinated drawing with managing the textual and numerical project information. This feature will lead to improve the team collaboration throughout the project phases, from conception to the demolition and materials recycling phase. At the design phase BIM visualizing and connecting to other analyzing systems, such as structural design, energy consumption, cost predicting, etc. During the construction stage, the design model will support the computer controlling prefabrication, project planning and resource requirement, building systems, and demolition.(1).

Traditional CAD planning environments typically do not have the capability of performing such analyses in early stages of design development. (2).

\subsection{BIM and Sustainable Design}

Sustainability in engineering design and construction operations is a significant twenty-first-century topic. In addition to the initial cost, clients are focusing on life-cycle costs and facilities operation where they are able to measure the benefits of sustainable design and construction (6).

Sustainable design practicing could be easier, efficient, and cheaper by using BIM software which enable the design team, and other project parties, creating coordinated, digitizing and visualizing information and documentation for the design to be used accurately, simulating and analyzing project progress and appearance with cost estimating, , and optimizing the environmental impact for the project through entire lifecycle.(1).

The sustainable buildings design becomes easier and systematic by dependence of BIM.BIM in the recent years has emerged performing excellently in projects sustainable design.(10).

The combination of sustainable design strategies and BIM technology has the potential to change the traditional design

Volume 6 Issue 7, July 2017 


\section{International Journal of Science and Research (IJSR) \\ ISSN (Online): 2319-7064}

Index Coperni cus Value (2015): 78.96 | Impact Factor (2015): 6.391

practices and to produce a high performance facility design. (3). BIM could increase its capacity for integrating the environmental analysis and improving the design interoperability. The development of technology will enhance both sustainability and BIM in establishing standards of perfection in the future.(9).

If the buildings environmental impact were considered through the use of materials and energy during the project life cycle, then we could define their environmental performance as the actual abilityof the construction to make optimum use of the natural resources that available during its functional life to achieve the sustainability goals. (11).

\subsection{Life Cycle Costing}

One of most important functionality and technique of sustainable concepts used for business management is Life cycle costing (LCC) or more accurately Whole life costing (WLC). (7).

The LCC is technique that used for estimating and assessing the value and cost of the assets. The LCC is used for analyzing and determining whether a project performance meets client's requirements. (5).

Life cycle costing (LCC) is essential to get an information out of the module in the same time of design information comes in terms of stage gateways because without all this information client can't make the decision that need to make because that the business management is imperative form must clients, must clients build for profit on the public sector and they can't make the best decision on less information align to the design in formation. The most important for client will be in business management and decision must be made and the information in BIM module supports that business management decision making process. (2).

It is a flexible and can integrate with international building sustainability assessment methods and schemes by reporting life cycle costing in a number of ways including to the many methods/standards, the BS ISO 15686-5: 2008 is the guidelines for performance life cycle cost (LCC) analyses of buildings and constructed assets (7).

There are many programmers integrate with BIM and use for sustainable concepts analysison the market, such as GBS (Green Building Studio), Ecotect, IES VE (Integrated Environmental Solutions), eQuest, Energy Plus, Design Builder, HEED, etc. These programs used to study and analyze the building performance. The range of functional analysisincludes site analysis, visibility and right-to-light analysis, Water use analysis, Energy analysis, materials, LCC/LCA analysis, Day lighting/ Solar analysis, etc..(8).

\section{Research Methodology}

For the purpose of this research a questionnaire form was designed and created in 20 questions divided into four major sections, depending on previous surveys about BIM and the state of BIM market requirements in the Middle East region:(1) the Personal and organizational information, (2) implementation of Building Information Modeling (BIM),
(3) BIM technical information including sustainable concepts,(4) investigating the technical opinion for the respondents. Two skip-logic questions were used in the questionnaire form. The first one used at the end of the first part, the respondents who didn't use BIM will skip to the end of the questionnaire, otherwise he/she will continue to the second parts. The second skip-logic questions used in the end of the second part of the questionnaire, the respondents who use sustainable concepts will continue to the third part, otherwise he will skip to the end of the questionnaire. The questionnaire form involves many questions as a multiple choices question, which means that the respondent can choose more than one answer for one question.

The survey responses involve BIM specialists in the Middle East when meeting them in the Middle East BIM Summit (ME BIM Summit 2016) which held in Dubai, in November 2016. The questionnaire forms send to them later using the LinkedIn professional network to the BIM specialists in Gulf Cooperation Council (GCC). The questionnaire form created by using the Web-Based Survey Solutions (www.surveymonkey.com). The next step after distributing and collecting the questionnaire forms are analysis the answers using statistical methods and procedures. The researcher will use some statistical methods to data analysis including reliability and validity test and Frequency analysis of multiple responses questions.

\section{Survey Results: Statistical Analysis}

Until the survey closed 76 individuals visited the survey link and only 64 visitors complete answering the questionnaire, while the other 12 visitors failed in answering the questions. So the researcher decides to eliminate uncompleted responses to ensure maximum consistency in the reported results. The survey response rate is $84.2 \%$ which is good enough to engage signification.

\subsection{Reliability and Validity Test}

For the two ranking question we will perform the reliability and Validity Test. Reliability means that the questionnaire will give the same results when re-applying several times on the same sample under the same conditions, in other words, the reliability of the questionnaire means stability in its results that do not change significantly as a result redistributed several times between the samples during the same time period. While Validity has many definitions which reflect the questionnaire content required to be measured according to relative weights. Mathematically, it is equal to the square root of the coefficient of reliability.

The coefficient of alpha gives the minimum limit for value estimated of the reliability coefficient, if the value of alpha is high (close to one), this already indicates the reliability of the questionnaire. So the values of Cronbach's alpha coefficients are calculated for measuring reliability, by using (SPSS) program according to equation (1).

$$
\alpha=\frac{\mathrm{K}}{\mathrm{K}-1}\left(1-\frac{\sum_{\mathrm{i}} \mathrm{Si}^{2}}{\mathrm{St}^{2}}\right)
$$

Where:

$\alpha$ : Cronbach alpha coefficient.

$\mathrm{K}$ : number of elements in-group. 
International Journal of Science and Research (IJSR)

ISSN (Online): 2319-7064

Index Coperni cus Value (2015): 78.96 | Impact Factor (2015): 6.391

$\mathrm{Si}$ : element of variance.

St: the variance of total score of the elements.

Alpha coefficient expresses the degree of internal consistency of the scale that ranging between (0-1). The coefficient of Cronbach Alpha supposed to be not less than (0.70). To implement the above equation and test the reliability, the researcher will use the responses of the questionnaire sample about the forth section of the questionnaire form ( Technical Opinion) as shown in the tables (1) and (2) the values of the reliability coefficients are positive with convergence in their values for the two ranking questions. The maximum limit of Cronbach's Alpha coefficient is (0.927)for questions in table (1) and (0.841)for questions in table (2), while the minimum limit is $(0.913)$ and (0.814) respectively. According to these results, the reliability coefficients of the study tool are high, which indicates the availability of a high degree of stability for the questionnaire answers in addition to validity.

Table 1: Reliability test results (first ranking question)

\begin{tabular}{|c|c|c|}
\hline $\mathrm{N}$ & Questions & $\begin{array}{c}\text { Cronbach's } \\
\text { Alpha }\end{array}$ \\
\hline 1 & BIM reduce the financial risk & 0.923 \\
\hline 2 & BIM shorten project schedule & 0.925 \\
\hline 3 & BIM obtain reliable and accurate cost estimates & 0.923 \\
\hline 4 & BIM assure program compliance & 0.922 \\
\hline 5 & $\begin{array}{c}\text { BIM optimize facility management and } \\
\text { maintenance }\end{array}$ & 0.923 \\
\hline 6 & $\begin{array}{c}\text { BIM integrate development of programmatic and } \\
\text { feasibility phase requirement }\end{array}$ & 0.913 \\
\hline 7 & $\begin{array}{c}\text { BIM reduce time to market through the use of } \\
\text { parametric models }\end{array}$ & 0.924 \\
\hline 8 & BIM increase building performance & 0.923 \\
\hline 9 & BIM increases the design quality & 0.923 \\
\hline 10 & BIM will improve the construction industry & 0.923 \\
\hline 11 & BIM will improve the building energy efficiency & 0.924 \\
\hline 12 & $\begin{array}{c}\text { BIM will improve the communications between } \\
\text { project's parties }\end{array}$ & 0.922 \\
\hline 13 & BIM simplify all the project stages & 0.926 \\
\hline 14 & BIM helps in conflict resolution & 0.923 \\
\hline 15 & $\begin{array}{c}\text { BIM helps in applying sustainable requirement } \\
\text { (LEED) }\end{array}$ & 0.923 \\
\hline 16 & Using BIM will reduce the variation orders & 0.923 \\
\hline 17 & $\begin{array}{c}\text { productivity The more detailed model the less } \\
\text { error occurred }\end{array}$ & 0.927 \\
\hline
\end{tabular}

Table 2: Reliability test results (second ranking question)

\begin{tabular}{|c|c|c|}
\hline $\mathrm{N}$ & Questions & $\begin{array}{c}\text { Cronbach's } \\
\text { Alpha }\end{array}$ \\
\hline 1 & Less time drafting more time designing & 0.835 \\
\hline 2 & Owners demanding on the ir projects & 0.841 \\
\hline 3 & $\begin{array}{c}\text { BIM improve clients communication with others } \\
\text { project parties in design and construction phase }\end{array}$ & 0.821 \\
\hline 4 & Parametric modification of design with BIM & 0.827 \\
\hline 5 & Opportunity for construction cost reduction & 0.818 \\
\hline 6 & Enhancedocumentation version control & 0.821 \\
\hline 7 & Enhance budgeting and cost estimating & 0.819 \\
\hline 8 & Opportunity for construction time reduction & 0.823 \\
\hline 9 & Clash detection capabilities of BIM tools & 0.835 \\
\hline 10 & Reducing insurance claims because of BIM & 0.832 \\
\hline 11 & Enhance scheduling capabilities using BIM tools & 0.814 \\
\hline 12 & Compliance design code checking & 0.832 \\
\hline 13 & Safer work sites by us ing BIM & 0.840 \\
\hline 14 & Reduced number/need for information requests & 0.829 \\
\hline
\end{tabular}

\subsection{Personal and organi zational information}

This section consists of analyzing the general information regarding the features and characteristics of the study sample. The experience years of the respondents divided into four categories (less than 5 years, 5-10 years, 10-15 years, and more than 15 years). The results indicate that $21.90 \%$ have more than 15 years' experience, $17.20 \%$ have $10-15$ years' experience, $20.30 \%$ have 5-10 years' experience, and $40.60 \%$ have less than 5 years' experience.

The results of the respondent work sector indicate that $9.40 \%$ work in public sector, $67.20 \%$ work in private sector, and $23.40 \%$ work in both (public and private).

The result shows that the specialty of responses is $32.80 \%$ architecture, $4.70 \%$ consulting, $31.30 \%$ management (BIM manager), $20 \%$ engineering, $1.60 \%$ estimating, and the category "Other" $9.40 \%$.

The result of the respondent's position in their organization illustrated that $14.40 \%$ manager or director, $14.40 \%$ consultant, $9.40 \%$ designer, $37.50 \%$ responsible for BIM implementation, $4.70 \%$ CAD technician, $1.60 \%$ academic/ teach site manager, and $18.80 \%$ "Other" category.

Concerning the role of the organizations, which the respondents work for, shows that $8.40 \%$ owner, $23.20 \%$ architecture, $17.90 \%$ project management, $25.30 \%$ consulting, $14.70 \%$ contractor (general or subcontractor), and the category "Other" $10.50 \%$.

Finally the type of the projects that the respondent companies deal with was shown in table (3). The result indicates that residential, commercial, mixed, educational, and healthcare are the most type of projects worked.

Table 3: projects type deals with

\begin{tabular}{|c|l|c|c|}
\hline \multicolumn{2}{|c|}{ Project types } & \multicolumn{2}{c|}{ Response } \\
\cline { 3 - 4 } \multicolumn{2}{|c|}{} & N & Percent \\
\hline 1 & Residential & 44 & $15.3 \%$ \\
\hline 2 & Commercial (Mall, office \& Retail) & 47 & $16.4 \%$ \\
\hline 3 & Mixed & 36 & $12.5 \%$ \\
\hline 4 & Educational & 30 & $10.5 \%$ \\
\hline 5 & Healthcare & 31 & $10.8 \%$ \\
\hline 6 & Industrial & 23 & $8.0 \%$ \\
\hline 7 & Infrastructure & 23 & $8.0 \%$ \\
\hline 8 & Worship facilities & 8 & $2.8 \%$ \\
\hline 9 & Entertainment & 14 & $4.9 \%$ \\
\hline 10 & Sport & 15 & $5.2 \%$ \\
\hline 11 & Power & 10 & $3.5 \%$ \\
\hline 12 & Other & 6 & $2.1 \%$ \\
\hline & Total & 287 & $100.0 \%$ \\
\hline
\end{tabular}

The last question in the first section of the questionnaire is a skip-logic question that ask if the respondents using BIM in their organizations. From the 64 respondents, 61 respondents $(95.30 \%)$ were currently use BIM technology in their projects, while 2 respondents $(3.10 \%)$ were planning to use BIM. 1 respondent $(1.60 \%)$ nonuse BIM in their projects and he will leave the questionnaire.

\section{Volume 6 Issue 7, July 2017 www.ijsr.net}


International Journal of Science and Research (IJSR)

ISSN (Online): 2319-7064

Index Coperni cus Value (2015): 78.96 | Impact Factor (2015): 6.391

\subsection{Implementation of Building Information Modeling}

This section aims to study the situation of implementation BIM, explaining BIM benefits, most BIM solution software used and the difficulties that resist adoption of BIM.

A- The benefits of adopting BIM in the organizations are stated in 10 benefits. The result that indicate that theIncreasing Building performance and quality, Improvement of collaboration between team members, Synchronization of design and construction planning are the most benefits achieved from BIM implementation as shown in table (4).

Table 4: benefits of adopting BIM

\begin{tabular}{|c|c|c|c|}
\hline \multicolumn{2}{|c|}{ Benefits } & \multicolumn{2}{c|}{ Responses } \\
\cline { 3 - 4 } & $\mathrm{N}$ & Percent \\
\hline 1 & Increasing Building performance and quality & 50 & $13.4 \%$ \\
\hline 2 & $\begin{array}{c}\text { Improvement of collaboration between team } \\
\text { members }\end{array}$ & 49 & $13.1 \%$ \\
\hline 3 & $\begin{array}{c}\text { Synchronization of design and construction } \\
\text { planning }\end{array}$ & 44 & $11.8 \%$ \\
\hline 4 & $\begin{array}{c}\text { Synchronization of procurement with design } \\
\text { and construction }\end{array}$ & 33 & $8.8 \%$ \\
\hline 5 & Extraction of cost estimates & 37 & $9.9 \%$ \\
\hline 6 & Competition and marketing & 29 & $7.8 \%$ \\
\hline 7 & $\begin{array}{c}\text { Discover the design errors and omissions } \\
\text { before construction }\end{array}$ & 49 & $13.1 \%$ \\
\hline 8 & $\begin{array}{c}\text { Use of design model as basis for fabrication } \\
\text { components }\end{array}$ & 21 & $5.6 \%$ \\
\hline 9 & $\begin{array}{c}\text { Improvement of energy efficiency and } \\
\text { sustainability }\end{array}$ & 24 & $6.4 \%$ \\
\hline 10 & Management and operation of facilities & 33 & $8.8 \%$ \\
\hline 11 & Other & 4 & $1.1 \%$ \\
\hline & Total & 373 & $100 \%$ \\
\hline
\end{tabular}

B-The most common BIM solution software used by the respondent organizations indicate that Autodesk Revit with 42.1\%, Autodesk Navisworks 25.6\%, Tekla Structures 10.5\% and the category "Other" included but was not limited 11.3\% most of it Civil 3D solution software as shown in table (5).

Table 5: BIM solution software used

\begin{tabular}{|c|c|c|c|}
\hline \multicolumn{2}{|c|}{ BIM solution software } & \multicolumn{2}{c|}{ Responses } \\
\cline { 3 - 4 } & $\mathrm{N}$ & Percent \\
\hline 1 & Autodesk Revit (Arch., Structure, MEP) & 56 & $42.1 \%$ \\
\hline 2 & $\begin{array}{l}\text { Bentley system (Arch, Structure, Mechanical, } \\
\text { Electrical) }\end{array}$ & 10 & $7.5 \%$ \\
\hline 3 & Tekla Structures & 14 & $10.5 \%$ \\
\hline 4 & Autodesk Navisw orks & 34 & $25.6 \%$ \\
\hline 5 & Graphis oftArchiCAD & 3 & $2.3 \%$ \\
\hline 6 & Vectorworks & 1 & $0.8 \%$ \\
\hline 7 & Other & 15 & $11.3 \%$ \\
\hline & Total & 133 & $100.0 \%$ \\
\hline
\end{tabular}

C-Difficulties resist adoptions of BIM in their organization are stated in 9 difficulties. The ans wers indicate that that the common difficultiesare (Staff training, Resistance to Change, Lack of client/owner demand, Integration of team members, Lack of government's lead/direction) as shown in table (6).
Table 6: Difficulties resist adoptions of BIM

\begin{tabular}{|c|l|c|c|}
\hline \multirow{2}{*}{\multicolumn{2}{|c|}{ Difficulties }} & \multicolumn{2}{c|}{ Responses } \\
\cline { 3 - 4 } & $\mathrm{N}$ & Percent \\
\hline 1 & Staff training & 33 & $20.6 \%$ \\
\hline 2 & Integration of team me mbers & 24 & $15.0 \%$ \\
\hline 3 & Lack of client/owner demand & 26 & $16.3 \%$ \\
\hline 4 & Lack of government's lead/direction & 20 & $12.5 \%$ \\
\hline 5 & Getting BIM software & 6 & $3.8 \%$ \\
\hline 6 & Resistance to Change & 29 & $18.1 \%$ \\
\hline 7 & Management of Information & 9 & $5.6 \%$ \\
\hline 8 & Perceived Costs & 10 & $6.3 \%$ \\
\hline 9 & Other & 3 & $1.9 \%$ \\
\hline & Total & 160 & $100.0 \%$ \\
\hline
\end{tabular}

The last question in the second section is a skip-logic question about (Does your organization adopt sustainable concepts), if the answer is yes then the respondent continue to the third section of questionnaire otherwise the respondent will move to the forth part without passing in the third part. The answers of respondent shows that $76.20 \%$ adopt sustainable concepts in their organizations and $23.80 \%$ not adopt.

\subsection{Technical information about BIM-Sustainable integration}

In this section the researcher will focuses on the sustainable concepts and how to be integrated with BIM. Also the researcher will investigate how to get benefits from this integration in achieving project goals.

A-The first question asks about the use Sustainable concepts in BIM work by the respondent organizations. $57.8 \%$ of the respondents indicate that their organization has benefited of BIM-Sustainable integration and $42.20 \%$ not adopt BIMSustainable Integration. This result give us an indication about the ability and important of including sustainable concepts in BIM in the future projects.

B-Exactly half of the respondents stated that they (or their organization) use LEED rating system in certifying sustainable building, while $(12.9 \%)$ indicate that they use BREEAM in certifying process, the other results illustrated in table (7).

Table 7: using of rating system in certifying sustainable building

\begin{tabular}{|c|c|c|c|}
\hline \multicolumn{2}{|c|}{ Rating Systems } & \multicolumn{2}{|c|}{ Responses } \\
\cline { 3 - 4 } & $\mathrm{N}$ & Percent \\
\hline 1 & $\begin{array}{c}\text { LEED (Leadership in Energy and } \\
\text { Environmental Design) }\end{array}$ & 31 & $50.0 \%$ \\
\hline 2 & $\begin{array}{c}\text { BREEAM (Building Research Establishment } \\
\text { Environmental Assessment Method) }\end{array}$ & 8 & $12.9 \%$ \\
\hline 3 & Green Globes & 1 & $1.6 \%$ \\
\hline 4 & $\begin{array}{c}\text { CASBEE (Comprehensive Assessment } \\
\text { System for Built Environment Efficiencies) }\end{array}$ & 1 & $1.6 \%$ \\
\hline 5 & Pearl Building Rating System & 3 & $4.8 \%$ \\
\hline 6 & HQE (High Quality Environmental standard) & 2 & $3.2 \%$ \\
\hline 7 & DGNB & 3 & $4.8 \%$ \\
\hline 8 & Green Star & 3 & $4.8 \%$ \\
\hline 9 & GBI (Green Building Index) & 2 & $3.2 \%$ \\
\hline 10 & Other & 8 & $12.9 \%$ \\
\hline & Total & 62 & $100 . \%$ \\
\hline
\end{tabular}

C-The result of uses of sustainable analysis software adopted

\section{Volume 6 Issue 7, July 2017 www.ijsr.net}




\section{International Journal of Science and Research (IJSR) \\ ISSN (Online): 2319-7064}

Index Coperni cus Value (2015): 78.96 | Impact Factor (2015): 6.391

by their organization shows that that $(25.9 \%)$ of the respondent use (GBS) software. (22.2\%) indicate they are using (Ecotect) software. (18.5\%) agreed they are using (IES VE) software in sustainable analysis, while (20.4\%) select (other) in their response as shown in table (8).

Table 8: uses of sustainable analysis software

\begin{tabular}{|c|c|c|c|}
\hline \multicolumn{2}{|c|}{ Sustainable solution Software } & \multicolumn{2}{c|}{ Responses } \\
\cline { 3 - 4 } \multicolumn{2}{|c|}{} & $\mathrm{N}$ & Percent \\
\hline 1 & IES VE (Integrated Environmental Solutions) & 10 & $18.5 \%$ \\
\hline 2 & GBS ( Green Building Studio) & 14 & $25.9 \%$ \\
\hline 3 & Ecotect & 12 & $22.2 \%$ \\
\hline 4 & Energy Plus & 7 & $13.0 \%$ \\
\hline 5 & Other & 11 & $20.4 \%$ \\
\hline & Total & 54 & $100.0 \%$ \\
\hline
\end{tabular}

D-The result of project stage BIM-sustainable analysis performed indicate that $(34.9 \%)$ in design stage and(28.3\%) in planning stage, followed by construction stage (18.9\%), operation and maintenance $(13.2 \%)$. The remaining for demolition $(2.8 \%)$ and other $(1.9 \%)$ as presented in table (9).

Table 9: project stage BIM-sustainable analysis performed

\begin{tabular}{|c|l|c|c|}
\hline \multicolumn{2}{|c|}{ Project Stages } & \multicolumn{2}{c|}{ Responses } \\
\cline { 3 - 4 } & N & Percent \\
\hline 1 & Planning & 30 & $28.3 \%$ \\
\hline 2 & Design & 37 & $34.9 \%$ \\
\hline 3 & Construction & 20 & $18.9 \%$ \\
\hline 4 & Operation and Maintenance & 14 & $13.2 \%$ \\
\hline 5 & Disposal and demolition & 3 & $2.8 \%$ \\
\hline 6 & Other & 2 & $1.9 \%$ \\
\hline & Total & 106 & $100.0 \%$ \\
\hline
\end{tabular}

E-The results of the functionality types of BIM-sustainability analysis indicate that $(22.8 \%)$ using BIM-sustainable functional analysis for energy analysis and (15.2\%) for Day lighting/ Solar analysis. The results for this question illustrated in table (10) below.

Table 10: functionality types of BIM-sustainability analysis

\begin{tabular}{|c|l|c|c|}
\hline \multirow{2}{*}{ BIM-Sustainable Functional analys is } & \multicolumn{2}{|c|}{ Responses } \\
\cline { 3 - 4 } & N & Percent \\
\hline 1 & Energy analys is & 36 & $22.8 \%$ \\
\hline 2 & materials, LCC/LCA analys is & 23 & $14.6 \%$ \\
\hline 3 & Day lighting/ Solar analys is & 24 & $15.2 \%$ \\
\hline 4 & Glazing analys is & 11 & $7.0 \%$ \\
\hline 5 & Massing analys is & 11 & $7.0 \%$ \\
\hline 6 & LEED/ BREEAM doc umentation & 20 & $12.7 \%$ \\
\hline 7 & Acoustic analys is & 6 & $3.8 \%$ \\
\hline 8 & Water use analys is & 9 & $5.7 \%$ \\
\hline 9 & Site analysis & 16 & $10.1 \%$ \\
\hline 10 & Other & 2 & $1.3 \%$ \\
\hline & Total & 158 & $100.0 \%$ \\
\hline
\end{tabular}

F-The last question concern using LCA/LCC analysis, $(30.8 \%)$ of the respondent indicate that they don't use LCA/LCC analysis, while $(21.5 \%)$ of the respondent use LCA/LCC analysis in Project development/ planning phase. The rest of the respondent use the LCA/LCC analysis in Preliminary/ Conceptual design $(12.3 \%)$, Investigation phase $(10.8 \%)$, detailed design phase $(9.2 \%)$, Submission planning $(7.7 \%)$, and Construction phase $(7.7 \%)$ as shown in table (11).This result reflects the important of using LCA/LCC analysis in different project phases especially in planning and design phase.
Table 11: Phases of use LCA/LCC

\begin{tabular}{|c|c|c|c|}
\hline \multirow{2}{*}{ Phase of use LCA/LCC } & \multicolumn{2}{c|}{ Responses } \\
\cline { 3 - 4 } & $\mathrm{N}$ & Percent \\
\hline 1 & Project development/ planning phase & 14 & $21.5 \%$ \\
\hline 2 & Investigation phase & 7 & $10.8 \%$ \\
\hline 3 & $\begin{array}{c}\text { Preliminary/ Conceptual design/ architects' } \\
\text { competition }\end{array}$ & 8 & $12.3 \%$ \\
\hline 4 & Submission planning & 5 & $7.7 \%$ \\
\hline 5 & $\begin{array}{c}\text { Detailed design phase/ Implementation } \\
\text { planning }\end{array}$ & 6 & $9.2 \%$ \\
\hline 6 & Construction phase & 5 & $7.7 \%$ \\
\hline 7 & I don't use LCA/LCC & 20 & $30.8 \%$ \\
\hline & Total & 64 & $100.0 \%$ \\
\hline
\end{tabular}

\subsection{Technical opinion}

The last section involves three questions to be answered from all respondents as a technical opinion. A-The first question about the agreement with which BIM definition, According to the experience and understanding of the respondents about BIM, they agree with 6th definition for BIM technology that's say ((BIM is not just software-rather, it is a process and software. Taking that one step further, we now see that successful BIM use requires three key factors, Processes, Technologies, Behaviors.(BIM and construction management 2015)). The result for this question presented in table (12).

Table 12: BIM definition

\begin{tabular}{|c|c|c|c|}
\hline \multirow{2}{*}{\multicolumn{2}{|c|}{ BIM definition }} & \multicolumn{2}{|c|}{ Responses } \\
\hline & & $\mathrm{N}$ & Percent \\
\hline 1 & $\begin{array}{l}\text { BIM is a "set of interacting policies, process } \\
\text { and technologies generating a methodology } \\
\text { to manage the essential building design and } \\
\text { project data in digital format throughout the } \\
\text { building life cycle" (Penttilä 2006, } \\
\text { Succar2009) }\end{array}$ & 27 & $17.5 \%$ \\
\hline 2 & $\begin{array}{l}\text { BIM is a "shared digital representation of } \\
\text { phys ical and functional characteristics of any } \\
\text { built objects which form a reliable bas is for } \\
\text { decis ion" (ISO Standard } 2010 \text {, Volk, Stengel } \\
\text { et al. 2014) }\end{array}$ & 19 & $12.3 \%$ \\
\hline 3 & $\begin{array}{l}\text { BIM is "The process of creating and using } \\
\text { digital models for design, construction and/or } \\
\text { operation of projects" (Young, Jones et al. } \\
2009 \text { ) }\end{array}$ & 27 & $17.5 \%$ \\
\hline 4 & $\begin{array}{l}\text { BIM is "an intelligent 3D virtual building } \\
\text { model that can be constructed digitally by } \\
\text { containing all aspects of building information } \\
\text { - into an intelligent format that can be used } \\
\text { to deve lop optimized building solution with } \\
\text { reduce risk and increase values before } \\
\text { committing to design proposal" (Woo, } \\
\text { Wilsmann et al. 2010) }\end{array}$ & 21 & $13.6 \%$ \\
\hline 5 & $\begin{array}{l}\text { BIM is "an intelligent model base process } \\
\text { that provides insight to help you plan, design, } \\
\text { construct and manage buildings and } \\
\text { infrastructure" (Autodesk 2015) }\end{array}$ & 28 & $18.2 \%$ \\
\hline 6 & $\begin{array}{l}\text { BIM is not just software-rather, it is a process } \\
\text { and software. Taking that one step further, } \\
\text { we now see that successful BIM use requires } \\
\text { three key factors, Processes, Technologies, } \\
\text { Behaviors. (BIM and construction } \\
\text { management 2015) }\end{array}$ & 32 & $20.8 \%$ \\
\hline & Total & 154 & $100.0 \%$ \\
\hline
\end{tabular}

B-The last two questions in this section are the ranking 


\section{International Journal of Science and Research (IJSR) \\ ISSN (Online): 2319-7064 \\ Index Coperni cus Value (2015): 78.96 | Impact Factor (2015): 6.391}

questions, the first question ask about agreement of the responses with many statements about abilities of BIM, while the second question ask about agreement of responses onextent of influence BIM by many factors.

\subsection{Calculate the standard weight}

The researcher will give a weight for personal qualification of responses, so the suggested weight for the classes of experience years are shown in table (13).

Table 13: Personal qualification weight

\begin{tabular}{|c|c|c|}
\hline $\begin{array}{c}\text { Personal } \\
\text { Qualifications } \\
\end{array}$ & Data Description & $\begin{array}{c}\text { Standard } \\
\text { Weight }(\mathrm{SW})\end{array}$ \\
\hline \multirow{4}{*}{$\begin{array}{l}\text { Experience } \\
\text { years }\end{array}$} & $<5$ years & 1.0 \\
\hline & -10 years & 1.2 \\
\hline & $10-15$ years & 1.4 \\
\hline & $>15$ years & 1.6 \\
\hline
\end{tabular}

To quantify data analysis and calculate the arithmetic mean it is require to identifying a hypothetical weight value, for each answer of the five-scale ranking questions. We choose to correspond to the class mid-point that suggested by (Safar,
1999) as illustrated in Table (14).

Table 14: Weighted values of descriptive frequencies

\begin{tabular}{|c|c|c|}
\hline Descriptive Frequency & $\begin{array}{c}\text { Class } \\
\text { Interval }\end{array}$ & $\begin{array}{c}\text { Weight } \\
\text { value (WV) }\end{array}$ \\
\hline Strongly disagree/ Not Influence & $0-2$ & 1 \\
\hline Disagree/ Poor Influence & $2-4$ & 3 \\
\hline $\begin{array}{c}\text { Neither agree or disagree/ Neither } \\
\text { influence Nor not Influence }\end{array}$ & $4-6$ & 5 \\
\hline Agree/ Influence & $6-8$ & 7 \\
\hline Strongly agree/ Strongly influence & $8-10$ & 9 \\
\hline
\end{tabular}

The arithmetic mean (AM) can be calculated according to the following equation

$$
\mathrm{AM}=\frac{\sum \mathrm{WV} * \text { number of frequencies }}{\text { total number of answers }} .
$$

The first ranking question consists of 17 statements, and the second question consists of 14 statements. The tables (15) and (16), shows the calculation process of first statements in the first and second set of questions respectively. In the same way the researcher calculate the arithmetic mean for others statement.

Table 15: Calculation of arithmetic mean for first statement of first ranking question

\begin{tabular}{|c|c|c|c|c|c|c|}
\hline Degree of agreement & $\begin{array}{c}\text { Frequency } \\
\text { without personal } \\
\text { qualifications }\end{array}$ & $\begin{array}{c}\text { Percentage of } \\
\text { Freq. without } \\
\text { personal qual. }\end{array}$ & $\begin{array}{c}\text { Frequency with } \\
\text { personal } \\
\text { qualifications }\end{array}$ & $\begin{array}{c}\text { Percentage of } \\
\text { Freq. with } \\
\text { personal qual. }\end{array}$ & $\begin{array}{c}\text { Weighted } \\
\text { Value }\end{array}$ & Weighted Sc ore \\
\hline Strongly agree & 15 & $23.43 \%$ & 20 & $25 \%$ & 9 & $225 \%$ \\
\hline Agree & 35 & $54.68 \%$ & 44 & $55 \%$ & 7 & $385 \%$ \\
\hline Neither agree Nor disagree & 9 & $14.06 \%$ & 11 & $13.75 \%$ & 5 & $68.75 \%$ \\
\hline Disagree & 1 & $1.56 \%$ & 1 & $1.25 \%$ & 3 & $3.75 \%$ \\
\hline Strongly disagree & 4 & 6.27 & 5 & $5.0 \%$ & 1 & $5.0 \%$ \\
\hline Total & $\sum=64$ & $\sum=100 \%$ & $\sum=80$ & $\sum=100 \%$ & & $\sum=687.5 / 100 \%=6.875$ \\
\hline
\end{tabular}

Table 16: Calculation of arithmetic mean for first statement of second ranking question

\begin{tabular}{|c|c|c|c|c|c|c|}
\hline Degree of influence & $\begin{array}{c}\text { Freq. without } \\
\text { personal } \\
\text { qualifications }\end{array}$ & $\begin{array}{c}\text { Percentage of } \\
\text { Freq. without } \\
\text { personal qual. }\end{array}$ & $\begin{array}{c}\text { Frequency } \\
\text { with personal } \\
\text { qualifications }\end{array}$ & $\begin{array}{c}\text { Percentage of } \\
\text { Freq. with } \\
\text { personal qual. }\end{array}$ & $\begin{array}{c}\text { Weighted } \\
\text { Value }\end{array}$ & Weighted Score \\
\hline Strongly influence & 15 & $23.43 \%$ & 20 & $25.0 \%$ & 9 & $225 \%$ \\
\hline Influence & 32 & $50.0 \%$ & 38 & $47.5 \%$ & 7 & $332.5 \%$ \\
\hline Neither influence Nor not Influence & 13 & $20.31 \%$ & 17 & $21.25 \%$ & 5 & $106.25 \%$ \\
\hline Poor Influence & 4 & $6.26 \%$ & 5 & $6.25 \%$ & 3 & $18.75 \%$ \\
\hline Not influence & 0 & & 0 & $0 \%$ & 1 & $0 \%$ \\
\hline Total & $\sum=64$ & & $\sum=80$ & $\sum=100 \%$ & & $\sum=682.5 / 100 \%=6.825$ \\
\hline
\end{tabular}

After calculating the arithmetic mean (AM) for all statements in the first and second set of ranking questions, as shown in the two tables (17) and (18), the researcher focused on most abilities of BIM according the highest weighted score in the first set of ranking question.The results indicate that 6 statement secure arithmetic mean more than (7) (the mean of class interval of agree answer) as shown in figure (1). The researcher also focused on most points influence in use of BIM and the results indicate that 8 statements secure arithmetic mean more than (7) (the mean of class interval of influence answer) as shown in figure (2).

Table 17: Arithmetic means of first ranking question

\begin{tabular}{|c|c|c|}
\hline $\mathrm{N}$ & Statues & $\begin{array}{c}\text { Weighted } \\
\text { Score }\end{array}$ \\
\hline 1 & BIM reduce the financial risk & 6.87 \\
\hline 2 & BIM shorten project schedule & 6.35 \\
\hline 3 & BIM obtain reliable and accurate cost estimates & 6.78 \\
\hline 4 & BIM assure program compliance & 6.60 \\
\hline
\end{tabular}

\begin{tabular}{|c|c|c|}
\hline 5 & $\begin{array}{c}\text { BIM optimize facility management and } \\
\text { maintenance }\end{array}$ & 7.18 \\
\hline 6 & $\begin{array}{c}\text { BIM integrate development of programmatic and } \\
\text { feasibility phase requirement }\end{array}$ & 6.86 \\
\hline 7 & $\begin{array}{c}\text { BIM reduce time to market through the use of } \\
\text { parametric models }\end{array}$ & 6.33 \\
\hline 8 & BIM increase building performance & 6.93 \\
\hline 9 & BIM increases the design quality & 7.43 \\
\hline 10 & BIM will improve the construction industry & 7.94 \\
\hline 11 & BIM will improve the building energy efficiency & 7.01 \\
\hline 12 & $\begin{array}{c}\text { BIM will improve the communications between } \\
\text { project's parties }\end{array}$ & 7.70 \\
\hline 13 & BIM simplify all the project stages & 5.79 \\
\hline 14 & BIM helps in conflict resolution & 7.22 \\
\hline 15 & $\begin{array}{c}\text { BIM helps in applying sustainable requirement } \\
\text { (LEED) }\end{array}$ & 6.51 \\
\hline 16 & Using BIM will reduce the variation orders & 6.72 \\
\hline 17 & $\begin{array}{c}\text { Productivity The more detailed model the less error } \\
\text { occurred. }\end{array}$ & 6.22 \\
\hline
\end{tabular}

\section{Volume 6 Issue 7, July 2017 www.ijsr.net}




\section{International Journal of Science and Research (IJSR) \\ ISSN (Online): 2319-7064}

Index Coperni cus Value (2015): 78.96 | Impact Factor (2015): 6.391

1-BIM will improve the construction industry

2-BIM will improve the communications between project's parties

3-BIM increases the design quality

4-BIM helps in conflict res olution

5-BIM optimize facility management and maintenance

6-BIM will improve the building energy efficiency

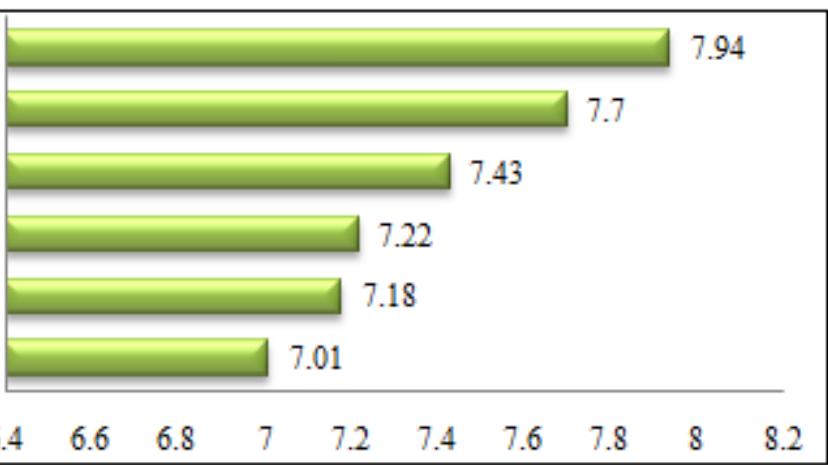

Figure 1: Statement with arithmetic mean more than 7 in first ranking question

Table 18: Arithmetic means of second ranking question

\begin{tabular}{|c|c|c|}
\hline N & Statues & Weighted score \\
\hline 1 & Less time drafting more time designing & 6.82 \\
\hline 2 & Owners demanding on the ir projects & 6.69 \\
\hline 3 & BIM improve clients communication with others project parties in design and construction phase & 7.40 \\
\hline 4 & Parametric modification of design with BIM & 7.27 \\
\hline 5 & Opportunity for construction cost reduction & 7.44 \\
\hline 6 & Enhance doc umentation version control & 7.22 \\
\hline 7 & Enhance budgeting and cost estimating & 7.15 \\
\hline 8 & Opportunity for construction time reduction & 7.08 \\
\hline 9 & Clash detection capabilities of BIM tools & 7.90 \\
\hline 10 & Reducing insurance claims because of BIM & 6.21 \\
\hline 11 & Enhance scheduling capabilities using BIM tools & 7.11 \\
\hline 12 & Compliance design code checking & 6.57 \\
\hline 13 & Safer work sites by using BIM & 6.08 \\
\hline 14 & Reduced number/need for information requests & 6.71 \\
\hline
\end{tabular}

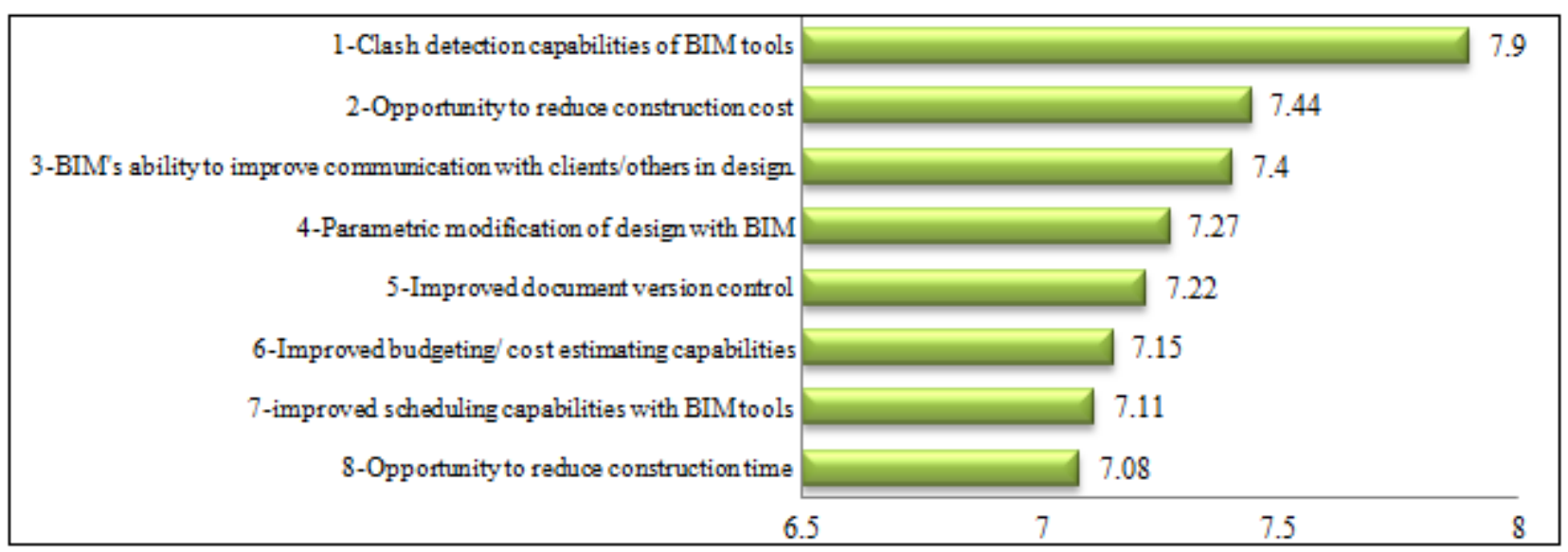

Figure 2: Statement with arithmetic mean more than 7 in second ranking question

\section{Conclusions and Recommendations}

The research explorer current use of BIM with sustainable design and construction and try to increase the existing knowledge about the use of BIM for improving the sustainability requirements. The survey results indicated that majorities $(95.30 \%)$ are currently using BIM in their project and $76.20 \%$ adopt sustainable concepts but only $57.8 \%$ of the respondents has benefited of BIM-Sustainable integration. The most benefits of adopting BIM are Increasing Building performance and quality, Improvement of collaboration between team members, Synchronization of design and construction planning. The most common BIM solution software used Autodesk Revit. Although the most difficulties resist adoption of BIM are staff training, resistance to change, lack of client/owner demand, integration of team members, and lack of government's lead/direction. $50 \%$ of the respondents stated that use Leadership in Energy and Environmental Design LEED rating system in certifying sustainable building. The common Performing use of BIM-sustainable analysis are in the design project stage with (34.90\%). Energy analysis is the common BIM-sustainable functional analysis tool used with (22.8\%). More than $(30 \%)$ of the respondent indicate that they don't use LCA/LCC analysis. Best BIM definition it was agreed to define is ((BIM is not just software-rather, it is a process and software. Taking that one step further, we now see that successful BIM use requires three key factors, Processes, Technologies, Behaviors.(BIM and construction management 2015)). The most abilities of BIM are BIM will improve the construction industry, BIM will improve the communications between project's parties, BIM increases the design quality, BIM helps in conflict resolution, BIM optimize facility management and maintenance, BIM will

\section{Volume 6 Issue 7, July 2017}

\section{www.ijsr.net}

Licensed Under Creative Commons Attribution CC BY 


\section{International Journal of Science and Research (IJSR) \\ ISSN (Online): 2319-7064 \\ Index Coperni cus Value (2015): 78.96 | Impact Factor (2015): 6.391}

improve the building energy efficiency. The most points influence in use of BIM are Clash detection capabilities of BIM tools, Opportunity to reduce construction cost, BIM improve clients communication with others project parties in design and construction phase, Parametric modification of design with BIM, Improved document version control, Improved budgeting/ cost estimating capabilities, improved scheduling capabilities with BIM tools, Opportunity to reduce construction time. Future researches should focuses on the benefits that can earned form use of BIM by integration with sustainable analysis tools for business management such as feasibility studies, cost management, and life-cycle costing analysis. It is an important for clients knowing the impact of the decision that takes according to design information on their business management.

\section{References}

[1] Autodesk, Inc., Building Information Modeling for Sustainable Design, 2011.

[2] Alan Muse, 2016. Medal East BIM Summit 2016 Measurement Standards- Space, Cost and Technology 2016

[3] Azhar, S., Brown, J., \&Farooqui, R. (2009). BIM-based sustainability analysis: An evaluation of building performance analysis software. Proceedings of the 45th ASC Annual Conference, Gainesville, Florida, April 14, 2009.

[4] Eastman, C., Teicholz, P., Sacks, R., and Liston, K. (2011). BIM Handbook: A Guide to Building Information Modeling for Owners, Managers, Designers, Engineers, and Contractors (2nd Ed.). John Wiley \& Sons.

[5] ISO 15686-5, Buildings and constructed assets-Servicelife planning part5, Life cycle costing, 2008

[6] J.K. Yates, Daniel Castro-Lacouture, Sustainability in Engineering Design and Construction, Taylor \& Francis Group, 2016.

[7] Keith Potts and NiiAnkrah: Construction cost management, Taylor \& Francis Group, second edition (2013).

[8] McGraw-Hill, Green BIM, How Building Information Modeling is Contributing to Green Design and Construction, 2010, http://www.wbdg.org/pdfs/mhc_smartmarket_rep2010.p df.

[9] Patrick Bynum, Raja R. A. Issa, and Svetlana Olbina: Building Information Modeling in Support of Sustainable Design and Construction. J. Constr. Eng. Manage.139:24-34. (2013).

[10] Sha Liu, Sustainable Building Design Optimization Using Building Information Modeling. ICCREM 2015 326-335 (2015).

[11] Stephen Emmitt, Architectural Technology Research \& Practice, Wiley \& Sons, Ltd, 2013.

\section{Author Profile}

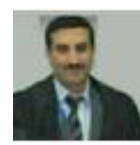

Ahmed Mahjoob received the B.Sc., MSc. and Ph.D. degrees in civil Engineering from Baghdad University in 2000, 2005, and 2014 respectively. During 20062016, he stayed work as a lecturer, lecture undergraduate stage in civil engineering department / University of
Baghdad, and from 2016 to now he lecturer also in graduate stage in construction project management and Supervis or for Master thesis.

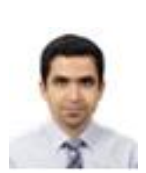

MohammedMahdi Abed received the B.Sc. degrees in civil Engineering from Kufa University in 2014. Now he is studying master degree in construction project management in the University of Baghdad. 